\title{
PENGARUH INTELLECTUAL CAPITAL DAN MEKANISME CORPORATE GOVERNANCE TERHADAP KINERJA KEUANGAN PADA PERUSAHAAN MANUFAKTUR YANG TERDAFTAR DI BURSA EFEK INDONESIA (BEI) PERIODE 2015-2017
}

\author{
Rizka Khairuni' ${ }^{1}$ Zahara $^{2}$, Elfitri Santi ${ }^{3}$ \\ Jurusan Akuntansi, Politeknik Negeri Padang \\ Email: rizka.khairuni@gmail.com ${ }^{1)}$, zahara@pnp.ac.id ${ }^{2)}$,elfitri@pnp.ac.id ${ }^{3)}$
}

\begin{abstract}
The purpose of this research is to find out the influence of intellectual capital and corporate governance mechanism to the financial performance. The independent variables are intellectual capital and corporate governance mechanism. Corporate governance mechanism in this research is measured by indicators which consist of institutional ownership, managerial ownership, the board of independent comissioner, and the board of director. The dependent variables is the financial performance which is measured by return on assets (ROA). The samples are 64 manufacturing companies which are listed in Indonesia Stock Exchange (IDX) in 2015-2017 periods were have been selected by using purposive sampling. Data analysis method in this research is multiple linear regressions analysis with the SPSS $20^{\text {th }}$ version application. The result of this research showed that partially, intellectual capital has positive influence to the financial performance. Meanwhile, corporate governance mechanism does not have any influence to the financial performance. Simultaneously, intellectual capital and corporate governance mechanism have positive influence to the financial performance.
\end{abstract}

Keywords: intellectual capital, corporate governance mechanism, financial performance

\begin{abstract}
ABSTRAK
Penelitian ini bertujuan untuk mengetahui pengaruh intellectual capital dan mekanisme corporate governance terhadap kinerja keuangan. Variabel independen pada penelitian ini adalah intellectual capital dan mekanisme corporate governance. Mekanisme corporate governance dalam penelitian ini diukur dengan indikator yang terdiri dari kepemilikan institusional, kepemilikan manajerial, dewan komisaris independen, dan dewan direksi. Variabel dependen pada penelitian ini adalah kinerja keuangan yang diukur dengan return on assets (ROA). Sampel dalam penelitian ini terdiri atas 64 perusahaan manufaktur yang terdaftar di Bursa Efek Indonesia (BEI) selama periode 2015-2017 yang dipilih menggunakan metode purposive sampling. Metode analisis data yang digunakan adalah analisis regresi linear berganda dengan menggunakan aplikasi SPSS versi 20. Hasil penelitian ini menunjukkan bahwa secara parsial, intellectual capital berpengaruh positif terhadap kinerja keuangan. Sedangkan mekanisme corporate governance tidak berpengaruh terhadap kinerja keuangan. Secara simultan, intellectual capital dan mekanisme corporate governance berpengaruh positif terhadap kinerja keuangan.
\end{abstract}

Kata kunci: intellectual capital, mekanisme corporate governance, kinerja keuangan 


\section{PENDAHULUAN}

Perkembangan ilmu pengetahuan dan teknologi dari tahun ke tahun semakin meningkat yang ditandai dengan munculnya inovasi-inovasi pembuatan produk atau jasa. Inovasi tersebut tidak hanya diiringi dengan peningkatan kekayaan fisik, tetapi juga dengan keahlian karyawan dan pengembangan teknologi oleh perusahaan dalam menghadapi persaingan usaha setelah munculnya masyarakat ekonomi ASEAN (MEA). Hal ini menuntut perusahaan untuk mengubah strategi bisnis dari berbasis pada tenaga kerja menjadi bisnis berbasis pada pengetahuan. Dengan berbasis ilmu pengetahuan, perusahaan dapat meningkatkan investasi terhadap aset tidak berwujud (intangible assets) salah satunya yaitu intellectual capital.

Penerapan intellectual capital dalam lingkungan bisnis global merupakan hal yang baru, begitu juga di Indonesia. Fenomena intellectual capital di Indonesia mulai berkembang setelah munculnya PSAK No. 19 (revisi 2015) tentang aset tidak berwujud yang terdiri dari ilmu pengetahuan dan teknologi, desain dan implementasi sistem atau proses baru, lisensi, hak kekayaan intelektual, pengetahuan mengenai pasar dan merek dagang (termasuk merek produk/brand names). Walaupun dalam PSAK 19 tidak disebutkan secara jelas tentang intellectual capital, tetapi menyiratkan intellectual capital karena intellectual capital merupakan salah satu bagian dari aset tidak berwujud.

Intellectual capital di dalam perusahaan merupakan sumber daya pengetahuan yang didasari oleh karyawan, pelanggan, proses, dan teknologi yang digunakan perusahaan dalam penciptaan nilai (Bukh et al, 2005). Secara umum, banyak peneliti yang menyatakan bahwa intellectual capital terdiri dari tiga elemen utama yaitu human capital, structural (organizational) capital, relational (costumer) capital. Human capital mencerminkan pengetahuan yang dimiliki oleh karyawan dalam perusahaan. Structural (organizational) capital meliputi sistem, prosedur, dan struktur perusahaan yang mendukung karyawan untuk menghasilkan kinerja yang optimal. Relational (costumer) capital mencerminkan hubungan yang harmonis yang dimiliki oleh perusahaan dengan para mitranya.

Selain intellectual capital, yang dapat berkontribusi terhadap kinerja keuangan yaitu penerapan corporate governance yang baik. Penerapan corporate governance sudah menjadi kebutuhan dalam kegiatan bisnis perusahaan agar dapat bersaing dan bertahan di dalam persaingan bisnis. Peningkatan terhadap kinerja dan nilai perusahaan serta kelangsungan usaha yang lama merupakan manfaat dari adanya penerapan corporate governance yang baik.

Indikasi munculnya corporate governance berkaitan dengan agency theory yang menjelaskan prilaku dari pihak-pihak yang terlibat dalam perusahaan karena memiliki kepentingan yang berbeda-beda. Adanya masalah diantara manajer (agent) dan pemegang saham (principal) yang disebut dengan masalah agensi akan menyebabkan tujuan keuangan perusahaan untuk meningkatkan nilai perusahaan dengan cara memaksimalkan kesejahteraan pemegang saham tidak dapat tercapai. Pemegang saham (principal) sebagai pemilik perusahaan berkewajiban menyediakan sarana dan dana untuk kegiatan operasi perusahaan. Sedangkan manajer (agent) sebagai pengelola perusahaan berkewajiban mengurus jalannya perusahaan yang diamanatkan oleh principal kepadanya. Dengan adanya mekanisme corporate governance dapat mengurangi terjadinya masalah keagenan karena mampu mengendalikan pihak-pihak yang terlibat dalam pengelolaan perusahaan dan 
menselaraskan perbedaan kepentingan antara agent dengan principal, principal (pemegang saham) dengan principal lainnya (pemberi pinjaman), serta diantara pihak-pihak yang berkepentingan (Wardani dan Zulkifli, 2017). Penerapan mekanisme corporate governance yang tepat dapat meningkatkan efektivitas perusahaan tersebut sehingga dapat melaporkan kegiatan usahanya dengan baik melalui laporan keuangan sebagai sumber informasi kepada stakeholder (Sari dan Priyadi, 2017).

Kinerja keuangan merupakan gambaran dari kondisi keuangan sebuah perusahaan pada periode tertentu. Kinerja keuangan perusahaan sangat penting diukur dan diketahui perkembangannya karena berguna untuk pengambilan keputusan dalam menetapkan kebijakan oleh pihak manajemen perusahaan. Pertimbangan dan minat para investor untuk menanamkan modalnya terhadap suatu perusahaan di pasar modal juga dipengaruhi oleh kinerja keuangan yang tercermin dalam laporan keuangan perusahaan tersebut. Kinerja perusahaan yang baik dapat dinilai dari kemampuan perusahaan mengelola modal secara efektif untuk menghasilkan pendapatan serta tingkat keuntungan yang diperoleh dari investasi yang dilakukan pemilik modal dan pemegang saham perusahaan. Oleh sebab itu, perusahaan harus mengetahui ukuran kinerja yang dapat meningkatkan kinerja perusahaan. Jika kinerja perusahaan terukur, maka akan menciptakan nilai perusahaan yang dapat dilihat oleh pihak-pihak yang berkepentingan. Dengan adanya pengelolaan intellectual capital dan penerapan mekanisme corporate governance yang baik akan meningkatkan kinerja keuangan perusahaan dan memberikan nilai tambah bagi perusahaan itu sendiri sehingga menciptakan keunggulan kompetitif dan menjamin kelangsungan hidup perusahaan.

Berdasarkan uraian yang telah dijelaskan diatas, maka penulis tertarik melakukan penelitian mengenai pengaruh intellectual capital dan mekanisme corporate governance terhadap kinerja keuangan pada perusahaan manufaktur yang terdaftar di Bursa Efek Indonesia (BEI) periode 2015-2017. Mekanisme corporate governance dalam penelitian ini diukur dengan indikator yang terdiri dari kepemilikan institusional, kepemilikan manajerial, dewan komisaris independen, dan dewan direksi.

\section{TINJAUAN PUSTAKA \\ Intellectual Capital}

Menurut Stewart (1997) dalam Ramadhan dan Kurnia (2017), intellectual capital merupakan materi intelektual berupa informasi, pengetahuan, inovasi, pengalaman, yang dapat dimanfaatkan dalam menghasilkan aset yang mempunyai nilai tambah dan memberikan keunggulan bersaing. Bontis et al., (2001) menjelaskan bahwa intellectual capital adalah gabungan dari para pekerja dan wawasan organisasional, yang memberikan kontribusi terhadap keunggulan daya saing yang berkelanjutan. Pulic (2004) mengemukakan bahwa intellectual capital adalah seluruh karyawan, perangkat organisasi, dan kemampuan karyawan dan organisasi dalam menciptakan nilai tambah. Intellectual capital merupakan aset tidak berwujud berupa sumber daya berbasis pengetahuan yang berpusat pada sumber daya manusia yang pada intinya memberikan keunggulan bersaing serta menciptakan nilai bagi perusahaan.

Edvinson dan Malone (1997), Stewart (1997), Bontis et al., (2000) serta Ting dan Lean (2009) dalam Sari dan Priyadi (2017) mengelompokkan intellectual capital ke dalam tiga komponen yaitu human capital, structural capital, dan relational capital 
atau customer capital. Menurut Bontis et al., (2000), human capital mencerminkan individual knowledge stock suatu organisasi yang dipresentasikan oleh karyawannya. Human capital ini termasuk kompetensi, komitmen dan loyalitas karyawan terhadap perusahaan. Structural capital meliputi seluruh non-human storehouses of knowledge dalam organisasi. Structural capital ini termasuk database, organizational chart, process manual, strategies, routines dan segala hal yang membuat nilai perusahaan lebih besar dari nilai materialnya. Customer capital merupakan pengetahuan yang melekat dalam marketing channels dan customer relationship dimana suatu organisasi mengembangkan hal tersebut melalui proses berbisnis.

\section{Pengukuran Intellectual Capital dengan VAIC ${ }^{\mathrm{TM}}$}

Metode yang digunakan untuk mengukur kinerja intellectual capital sebuah perusahaan yaitu metode VAIC ${ }^{\text {тм }}$ (Value Added Intellectual Coefficient). Metode ini dikembangkan oleh Pulic (2004) yang menyajikan informasi tentang value creation efficiency dari aset berwujud (tangible asset) dan aset tidak berwujud (intangible asset) yang dimiliki perusahaan. VAIC $^{\mathrm{TM}}$ menggambarkan besarnya nilai yang tercipta dari setiap unit nilai moneter yang diinvestasikan pada sumber daya. Model ini dimulai dengan kemampuan perusahaan untuk menciptakan value added (VA). Value added adalah indikator paling objektif untuk menilai keberhasilan bisnis dan menunjukkan kemampuan perusahaan sebagai hasil intellectual capital. Value added dihitung sebagai selisih antara output dan input. Output mencakup penjualan dan pendapatan lain-lain, sedangkan input mencakup seluruh beban dan biaya kecuali beban karyawan. Biaya yang terkait dengan karyawan tidak diperlakukan sebagai biaya tetapi merupakan investasi. Pada intinya, aspek kunci dalam model Pulic adalah memperlakukan tenaga kerja sebagai entitas penciptaan nilai (value creating entity).

Value added dipengaruhi oleh efisiensi dari capital employee (CE), human capital (HC), structural capital (SC). Hubungan value added dengan capital employee atau dana yang tersedia (modal fisik) diformulasikan dengan capital employed efficiency, hubungan value added dan human capital diformulasikan dengan human capital efficiency, dan hubungan value added terhadap structural capital diformulasikan dengan structural capital efficiency. Capital employed efficiency menggambarkan nilai tambah perusahaan yang dihasilkan dari modal yang digunakan. Human capital efficiency (HCE) mengindikasikan kemampuan karyawan dalam menghasilkan nilai tambah pada perusahaan untuk setiap rupiah yang dikeluarkan pada karyawan. Structural capital efficiency (SCE) merupakan indikasi bagaimana keberhasilan structural capital dalam penciptaan nilai.

\section{Resource Based Theory}

Resource based theory adalah suatu pemikiran yang berkembang dalam teori manajemen strategik dan keunggulan kompetitif perusahaan yang meyakini bahwa perusahaan akan mencapai keunggulan apabila memiliki sumber daya yang unggul (Solikhah dkk., 2010). Teori ini membahas bagaimana perusahaan mengelola dan memanfaatkan sumber daya yang dimilikinya dengan baik sehingga memperoleh keunggulan kompetitif dan menciptakan nilai tambah bagi perusahaan tersebut. Menurut resource based theory perusahaan akan unggul dalam persaingan usaha dan memperoleh kinerja keuangan yang baik dengan cara memiliki, menguasai, dan memanfaatkan aset-aset strategis yang penting baik itu aset berwujud maupun aset tidak berwujud. Resource based theory meyakini bahwa perusahaan akan mencapai keunggulan apabila memiliki sumber daya yang unggul. Semakin baik pemanfaatan 
intellectual capital oleh perusahaan maka akan menambah nilai perusahaan tersebut serta meningkatkan kinerja keuangan yang baik pula. Oleh karena itu, intellectual capital menjadi kunci untuk menciptakan value added bagi perusahaan.

\section{Corporate Governance}

Corporate governance merupakan suatu sistem yang dirancang untuk mengarahkan pengelolaan perusahaan secara profesional berdasarkan prinsip-prinsip transparansi, akuntabilitas, tanggung jawab, independen, kewajaran dan kesetaraan. Secara teoritis pelaksanaan corporate governance yang baik dapat meningkatkan kinerja keuangan perusahaan, nilai perusahaan, mengurangi resiko yang mungkin dilakukan oleh dewan komisaris dengan keputusan-keputusan yang menguntungkan diri sendiri dan umumnya pelaksanaan corporate governance yang baik dapat meningkatkan kepercayaan investor (Tjager et al, 2003 dalam Prastya, 2013).

\section{Mekanisme Corporate Governance}

Mekanisme adalah cara kerja sesuatu yang tersistem untuk mempengaruhi persyaratan tertentu. Mekanisme corporate governance merupakan suatu prosedur dan hubungan yang jelas antara pihak yang mengambil keputusan dengan pihak yang melakukan kontrol terhadap keputusan tersebut (Triastuty dan Riduwan, 2017).

\section{Kepemilikan Institusional}

Kepemilikan institusional adalah saham perusahaan yang dimiliki oleh institusi atau lembaga yaitu perusahaan asuransi, bank, perusahaan investasi, dan kepemilikan institusi lain (Midiastuty dan Machfoedz, 2003 dalam Triastuty dan Riduwan, 2017). Dengan adanya investor institusional, akan meminimalisir penyelewengan yang mungkin dilakukan oleh manajer karena pengawasan terhadap kinerja keuangan serta keterlibatan dalam pengambilan keputusan oleh investor institusional. Semakin besar kepemilikan institusional maka semakin efisien pemanfaatan aset perusahaan.

\section{Kepemilikan Manajerial}

Menurut Wahidahwati (2002) dalam Sari dan Priyadi (2017) kepemilikan manajerial merupakan pemegang saham dari pihak manajemen yang secara aktif ikut dalam pengambilan keputusan perusahaan. Jansen dan Meckling (1976) dalam Triastuty dan Riduwan (2017) menyebutkan struktur kepemilikan manajerial merupakan salah satu mekanisme dalam corporate governance karena dengan kepemilikan manajerial dapat menurunkan conflict of interest yang disebabkan oleh perbedaan kepentingan antara pemilik dan manajer. Semakin besar kepemilikan saham oleh manajemen dalam perusahaan maka semakin produktif tindakan manajer dalam meningkatkan kinerja perusahaan.

\section{Dewan Komisaris Independen}

Menurut Komite Nasional Kebijakan Governance (2006) dalam Sari dan Priyadi (2017) menyatakan dewan komisaris independen adalah anggota dewan komisaris yang tidak berafiliasi dengan manajemen, anggota dewan komisaris lainnya dan pemegang saham pengendali serta bebas dari hubungan bisnis dalam bentuk apapun demi menjaga independensi. Dewan komisaris memegang peranan penting dalam mengarahkan strategi dan mengawasi manajemen dalam mengelola perusahaan untuk mencapai tujuan perusahaan. Dewan komisaris independen dapat memberikan pengawasan terhadap manajemen secara objektif dan efisien. Peraturan Otoritas Jasa 
Keuangan nomor 33/PJOK.04/2014 tentang direksi dan dewan komisaris emiten atau perusahaan publik yang menyatakan bahwa setiap emiten wajib memiliki komisaris independen sekurang-kurangnya 30\% dari jumlah keseluruhan dewan komisaris.

\section{Dewan Direksi}

Dewan direksi bertugas dan bertanggungjawab terhadap kinerja perusahaan dan menjalankan manajemen perusahaan. Dewan direksi menentukan kebijakan yang akan diambil dan strategi perusahaan untuk jangka pendek maupun jangka panjang. Dengan adanya dewan direksi yang melaksanakan tugasnya dengan baik maka kinerja perusahaan juga akan meningkat (Tumirin, 2007 dalam Triastuty dan Riduwan, 2017). Peraturan Otoritas Jasa Keuangan nomor 33/POJK.04/2014 menyebutkan paling kurang terdapat dua orang anggota direksi dalam perusahaan.

\section{Agency Theory}

Agency theory (teori keagenan) merupakan suatu kondisi yang terjadi pada suatu perusahaan dimana pihak manajemen sebagai pelaksana yang disebut lebih jauh sebagai agent dan pemilik modal (owner) sebagai principal membangun suatu kontrak kerjasama yang disebut dengan "nexus of contract", kontrak kerjasama ini berisi kesepakatan-kesepakatan yang menjelaskan bahwa pihak manajemen perusahaan harus bekerja secara maksimal untuk memberi kepuasan yang maksimal seperti profit yang tinggi kepada pemilik modal (owner). Implikasinya memungkinkan terjadinya sikap opportunistik (opportunistic behavior) di kalangan manajemen perusahaan dalam melakukan tindakan yang sifatnya disengaja. Pihak agent menguasai informasi secara sangat maksimal (full information) dan disisi lain pihak principal memiliki keunggulan kekuasaan (discretionary power) atau maksimalitas kekuasaan sehingga kedua pihak ini sama-sama memiliki kepentingan pribadi (self-interest).

Principal menginginkan return sebesar-besarnya atas investasi yang dilakukan, sedangkan agent menginginkan kompensasi yang besar atas kinerja yang dilakukan terhadap perusahaan. Oleh karena itu, dibutuhkan corporate governance sebagai efektivitas mekanisme untuk meminimalisasi konflik keagenan diantara agent dan principal. Corporate governance dapat digunakan sebagai alat untuk memonitor bahkan membatasi perilaku opportunistic manajer dalam melakukan pengungkapan informasi yang bersifat sukarela (Triastuty dan Riduwan, 2017). Dengan adanya corporate governance, diharapkan agen bertindak sesuai dengan kepentingan pemilik yaitu meningkatkan return perusahaan sehingga kinerja perusahaan meningkat (Tertius dan Christiawan, 2015).

\section{Kinerja Keuangan Perusahaan}

Kinerja keuangan perusahaan merupakan gambaran dari kondisi keuangan perusahaan yang dianalisis menggunakan rasio keuangan (Sukhemi, 2007 dalam Wijayani, 2017). Kinerja perusahaan mengukur kemampuan perusahaan dalam menciptakan nilai tambah bagi kelangsungan perusahaan di masa depan (Triastuty dan Riduwan (2017). Dalam penelitian ini menggunakan rasio profitabilitas yaitu return on asset (ROA). Analisis ROA mengukur kemampuan perusahaan menghasilkan laba dengan menggunakan total aset (kekayaan) yang dimiliki perusahaan setelah disesuaikan dengan biaya-biaya untuk mendanai aset tersebut. ROA memberikan ukuran yang lebih baik atas profitabilitas perusahaan karena menunjukkan 
efektivitas manajemen dalam mengelola aset untuk memperoleh pendapatan. Semakin tinggi nilai ROA, maka semakin efisien perusahaan menggunakan asetnya sehingga menunjukkan kinerja yang semakin baik karena akan menghasilkan keuntungan bagi perusahaan.

\section{Pengembangan Hipotesis}

\section{Pengaruh Intellectual Capital terhadap Kinerja Keuangan}

Resource based theory menyatakan perusahaan akan unggul dalam persaingan usaha dan memperoleh kinerja keuangan yang baik apabila memiliki dan memanfaatkan aset-aset strategis yang penting berupa aset berwujud dan aset tidak berwujud. Intellectual Capital merupakan kekayaan intelektual yang bertumpu pada sumber daya manusia yang ada di dalam perusahaan. Dengan adanya kemampuan sumber daya manusia yang baik, diharapkan menghasilkan kinerja yang baik bagi perusahaan sehingga profitabilitas return on asset (ROA) juga meningkat. Penelitian sebelumnya dilakukan oleh Prastya (2013) membuktikan bahwa intellectual capital berpengaruh terhadap kinerja keuangan. Hal ini menunjukkan bahwa perusahaan yang mengelola dan mengembangkan intellectual capital dengan baik, maka akan menciptakan keunggulan kompetitif sehingga meningkatkan profitabilitas (keuntungan) perusahaan dan meningkatkan kinerja keuangan perusahaan menjadi semakin baik. Berdasarkan uraian diatas, maka diajukan hipotesis penelitian sebagai berikut: H1 : Intellectual Capital berpengaruh positif terhadap kinerja keuangan perusahaan

\section{Pengaruh Mekanisme Corporate Governance terhadap Kinerja Keuangan}

Kepemilikan institusional dapat bertindak sebagai pihak yang memantau perusahaan. Semakin besar kepemilikan institusional semakin efisien pemanfaatan aset perusahaan dan diharapkan dapat menyelaraskan kepentingan manajemen dan stakeholders lainnya untuk meningkatkan kinerja perusahaan serta mencegah kecurangan yang dilakukan oleh manajemen. Investor institusional akan mengawasi secara profesional perkembangan investasi yang ditanamkan pada perusahaan dan memiliki tingkat pengendalian yang tinggi terhadap tindakan manajemen. Rimardhani dkk., (2016) membuktikan bahwa kepemilikan institusional berpengaruh positif dan signifikan terhadap kinerja perusahaan.

Kepemilikan manajerial dapat dikatakan sebagai pemegang saham dalam hal ini sebagai pemilik dalam perusahaan dari pihak manajemen. Semakin besar kepemilikan manajerial akan meningkatkan kinerja manajemen sehingga meningkatkan keuntungan perusahaan dan kinerja perusahaan. Dengan adanya kepemilikan saham oleh manajer, maka secara langsung manajer akan ikut mendapatkan manfaat atas keputusan yang diambilnya serta akan menanggung resiko apabila keputusan tersebut salah. Triastuty dan Riduwan (2017) membuktikan bahwa kepemilikan manajerial berpengaruh positif terhadap kinerja keuangan.

Dewan komisaris independen dapat bertindak sebagai penengah apabila tejadi perselisihan diantara para manajer internal dan mengawasi kebijakan manajemen. Komisaris independen merupakan posisi terbaik untuk melaksanakan fungsi pengawasan agar terciptanya perusahaan dengan corporate governance yang baik. Dengan adanya komisaris independen, diharapkan dapat memberikan fungsi pengawasan secara objektif dan independen terhadap perusahaan sehingga berdampak baik terhadap kinerja perusahaan. Sari dan Priyadi (2017) membuktikan 
bahwa dewan komisaris independen berpengaruh positif terhadap kinerja perusahaan.

Dewan direksi di dalam sebuah perusahaan akan menentukan kebijakan dan strategi perusahaan untuk jangka pendek maupun jangka panjang. Semakin banyak dewan direksi dalam perusahaan maka kinerja perusahaan menjadi semakin lebih baik karena adanya pengawasan yang dilakukan oleh dewan direksi sehingga akan meningkatkan keuntungan dan kinerja perusahaan. Sulistyowati dan Fidiana (2017) membuktikan bahwa dewan direksi memberikan pengaruh positif terhadap kinerja keuangan perusahaan.

Dengan adanya mekanisme corporate governance yang terdiri dari kepemilikan institusional, kepemilikan manajerial, dewan komisaris independen, dan dewan direksi dapat mengurangi terjadinya masalah keagenan karena mampu mengendalikan pihak-pihak yang terlibat dalam pengelolaan perusahaan dan menselaraskan perbedaan kepentingan antara agent dengan principal, principal (pemegang saham) dengan principal lainnya (pemberi pinjaman), serta diantara pihak-pihak yang berkepentingan (Wardani dan Zulkifli, 2017). Penerapan mekanisme corporate governance yang tepat dapat meningkatkan efektivitas perusahaan tersebut sehingga dapat melaporkan kegiatan usahanya dengan baik melalui laporan keuangan sebagai sumber informasi kepada stakeholder (Sari dan Priyadi, 2017). Penelitian yang dilakukan oleh Prastya (2013) membuktikan bahwa corporate governance berpengaruh terhadap kinerja keuangan. Putra dan Fidiana (2017) juga membuktikan bahwa corporate governance berpengaruh positif terhadap kinerja keuangan. Berdasarkan uraian diatas, maka diajukan hipotesis penelitian sebagai berikut:

H2 : Mekanisme Corporate Governance berpengaruh positif terhadap kinerja keuangan perusahaan

\section{Pengaruh Intellectual Capital dan Mekanisme Corporate Governance terhadap Kinerja Keuangan}

Hubungan antara intellectual capital dengan kinerja keuangan didukung oleh resource based theory. Perusahaan yang mengelola dan memanfaatkan sumber daya yang dimilikinya dengan baik akan memperoleh keunggulan kompetitif dan menciptakan nilai tambah bagi perusahaan tersebut. Sedangkan agency theory menunjukkan bahwa mekanisme corporate governance dapat menselaraskan perbedaan kepentingan antara pihak agen dan prinsipal sehingga pengelolaan perusahaan dapat berjalan dengan baik yang dapat meningkatkan kinerja keuangan perusahaan. Sari dan Priyadi (2017) membuktikan bahwa intellectual capital dan corporate governance secara bersama-sama berpengaruh terhadap kinerja perusahaan. Hal ini menunjukkan bahwa intellectual capital dan corporate governance memiliki kontribusi terhadap peningkatan kinerja keuangan perusahaan menjadi lebih baik. Berdasarkan uraian diatas, maka diajukan hipotesis penelitian sebagai berikut:

H3 : Intellectual Capital dan Mekanisme Corporate Governance berpengaruh positif terhadap kinerja keuangan perusahaan 
METODE PENELITIAN

Jenis Penelitian

Penelitian ini merupakan penelitian kuantitatif, yaitu penelitian yang menekankan pada pengujian teori-teori melalui pengukuran variabel-variabel penelitian dengan angka dan melakukan analisis data dengan prosedur statistik.

\section{Populasi Dan Sampel Penelitian}

Populasi dalam penelitian ini adalah perusahaan manufaktur yang terdaftar di Bursa Efek Indonesia (BEI) periode 2015-2017 yang berjumlah 144 perusahaan. Sampel penelitian ini diambil dengan metode purposive sampling yaitu pemilihan sampel berdasarkan pertimbangan dan kriteria tertentu. Berikut kriteria sampel yang ditentukan: (1) Perusahaan manufaktur yang terdaftar di Bursa Efek Indonesia selama tahun 2015-2017. (2) Perusahaan manufaktur yang mempubikasikan laporan keuangan secara lengkap dan continue selama tahun 2015-2017. (3) Perusahaan manufaktur yang tidak mengalami kerugian selama tahun 2015-2017. (4) Perusahaan manufaktur yang memiliki data terkait dengan penelitian selama tahun 2015-2017. Berdasarkan kriteria-kriteria diatas, maka diperoleh sampel penelitian sebanyak 64 perusahaan manufaktur yang memenuhi kriteria.

\section{Jenis Dan Sumber Data}

Jenis data yang digunakan dalam penelitian ini adalah data sekunder berupa laporan keuangan tahunan perusahaan manufaktur yang terdaftar di Bursa Efek Indonesia pada tahun 2015 hingga 2017.

\section{Variabel dan Definisi Operasional Variabel Variabel Dependen}

Variabel dependen merupakan variabel yang dipegaruhi atau akibat karena adanya variabel bebas. Variabel dependen yang digunakan dalam penelitian ini adalah kinerja perusahaan yang diproksikan dengan return on asset (ROA). ROA menggambarkan kemampuan perusahaan secara keseluruhan dalam menghasilkan keuntungan dengan jumlah seluruh aset yang tersedia (Syamsudin, 2013 dalam Rimardhani dkk., 2016). Semakin tinggi nilai ROA, maka semakin efisien perusahaan menggunakan asetnya sehingga menunjukkan kinerja yang semakin baik karena akan menghasilkan keuntungan bagi perusahaan. ROA dapat dihitung dengan menggunakan rumus sebagai berikut:

$$
\text { ROA }=\frac{\text { Laba bersih setelah pajak }}{\text { Total aset }}
$$

\section{Variabel Independen}

Variabel independen merupakan suatu jenis variabel yang menjelaskan atau mempengaruhi variabel lain. Variabel independen dalam penelitian ini terdiri dari intellectual capital dan mekanisme corporate governance.

\section{Intellectual Capital (VAIC ${ }^{\mathrm{TM}}$ )}

Intellectual Capital diukur dengan menggunakan metode yang dikembangkan oleh Pulic (2004) yaitu metode VAIC $^{\text {тм }}$ (Value Added Intellectual Coefficient). VAIC $^{\text {тм }}$ diperoleh dari penjumlahan dari komponen human capital efficiency (HCE), structural 
capital efficiency (SCE), dan capital employed efficiency (CEE). Perhitungan VAIC ${ }^{\mathrm{TM}}$ terdiri atas beberapa tahap, yaitu:

1. Menghitung Value Added (VA)

VA dihitung sebagai selisih antara output dan input, dengan rumus sebagai berikut:

Keterangan:

$$
\mathrm{VA}=\mathrm{OUT}-\mathrm{IN}
$$

OUT (Output) : Penjualan dan pendapatan lain-lain

IN (Input) : Beban dan biaya kecuali beban karyawan

2. Menghitung Human Capital Efficiency (HCE)

Human capital efficiency adalah indikator efisiensi nilai tambah (Value Added/VA) modal manusia. HCE menunjukkan berapa banyak VA yang diperoleh dari biaya yang dikeluarkan untuk karyawan. HCE dihitung dengan menggunakan rumus:

Keterangan:

$$
\mathrm{HCE}=\frac{V A}{\mathrm{HC}}
$$

HCE : Human Capital Efficiency, rasio dari VA terhadap HC

VA : Value Added

HC : Human Capital, beban karyawan

3. Menghitung Structural Capital Efficiency (SCE)

Structural Capital Efficiency adalah indikator efisiensi nilai tambah (Value Added/VA) modal struktural. SCE mengukur jumlah structural capital (SC) yang dibutuhkan untuk menghasilkan VA dan merupakan indikasi seberapa sukses SC dalam melakukan proses penciptaan nilai pada perusahaan. SCE dihitung dengan menggunakan rumus:

$$
\mathrm{SCE}=\frac{\mathrm{SC}}{\mathrm{VA}}
$$

Keterangan:

SCE : Structural Capital Efficiency, rasio dari SC terhadap VA

SC : Structural Capital, hasil pengurangan Value Added dan Human Capital

VA : Value Added

4. Menghitung Capital Employed Efficiency (CEE)

Capital Employed Efficiency adalah indikator efisiensi nilai tambah (Value Added/VA) modal yang digunakan. CEE menunjukkan berapa banyak VA yang dapat diciptakan oleh satu unit CE. CCE dihitung dengan menggunakan rumus:

Keterangan:

$$
\mathrm{CEE}=\frac{\mathrm{VA}}{\mathrm{CE}}
$$

CEE : Capital Employed Efficiency, rasio dari VA terhadap CE

VA : Value Added

CE : Capital Employed, total ekuitas

5. Menghitung Value Added Intellectual Coefficient (VAIC ${ }^{\mathrm{TM}}$ )

VAIC $^{\mathrm{TM}}$ merupakan penjumlahan dari 3 komponen, yaitu HCE, SCE, dan CEE.

$$
\mathrm{VAIC}^{\mathrm{T} M}=\mathrm{HCE}+\mathrm{SCE}+\mathrm{CEE}
$$




\section{Mekanisme Corporate Governance}

Mekanisme corporate governance diukur dengan menggunakan indikator kepemilikan institusional, kepemilikan manajerial, dewan komisaris independen, dan dewan direksi.

1. Kepemilikan Institusional (KI)

Kepemilikan institusional adalah kepemilikan saham yang dimiliki oleh pihak institusi seperti pemerintah, perusahaan asuransi, perusahaan investasi, bank, dan institusi lainnya. Kepemilikan institusional dapat diukur dengan rumus sebagai berikut:

$$
\mathrm{KI}=\frac{\text { Jumlah saham yang dimilikiinstitusi }}{\text { Jumlah saham beredar }} \times 100 \%
$$

\section{Kepemilikan Manajerial (KM)}

Kepemilikan manajerial adalah kepemilikan saham yang dimiliki oleh pihak manajemen perusahaan seperti direksi dan komisaris. Kepemilikan manjerial dapat diukur dengan rumus sebagai berikut:

\section{Dewan Komisaris Independen (DKI)}

$$
\mathrm{KM}=\frac{\text { Jumlah saham yang dimiliki manajemen }}{\text { Jumlah saham beredar }} \times 100 \%
$$

Dewan komisaris independen adalah anggota dewan komisaris yang tidak memiliki hubungan keluarga, keuangan, kepengurusan, kepemilikan saham, dan hubungan lainnya dengan komisaris, direksi, pemegang saham pengendali yang dapat mempengaruhi kemampuannya untuk bertindak independen. Dewan komisaris independen dapat diukur dengan rumus sebagai berikut:

$$
\text { DKI }=\frac{\text { Jumlah Dewan Komisaris Independen }}{\text { Jumlah Total Dewan Komisaris Perusahaan }} \times 100 \%
$$

4.

$$
\text { Dewan Direksi (DD) }
$$

Dewan direksi adalah anggota dewan yang bertanggung jawab penuh atas pengurusan dan pengelolaan perusahaan. Indikator yang digunakan untuk mengukur dewan direksi adalah jumlah anggota dewan direksi yang ada dalam perusahaan. Dewan direksi dapat diukur dengan rumus sebagai berikut:

Dewan Direksi = Jumlah anggota dewan direksi

\section{Teknik Pengumpulan Data}

Teknik pengumpulan data yang digunakan dalam penelitian ini adalah teknik dokumentasi dengan mengambil data sekunder berupa laporan keuangan tahunan perusahaan manufaktur yang telah dipublikasikan di BEI pada tahun 2015-2017 yang dapat di download dari www.idx.co.id.

\section{Teknik Analisis Data}

\section{Analisis Statistik Deskriptif}

Analisis statistik deskriptif adalah analisis yang paling mendasar untuk menggambarkan keadaan data secara umum. Statistik deskriptif memberikan gambaran atau deskripsi suatu data yang dilihat dari nilai rata-rata (mean), standar deviasi, maksimum, dan minimum. 


\section{Uji Asumsi Klasik}

Uji asumsi klasik bertujuan untuk mengetahui dan menguji kelayakan model regresi yang digunakan dalam penelitian ini. Uji asumsi klasik terdiri dari uji normalitas, uji multikolinieritas, uji autokorelasi dan uji heteroskedastisitas.

\section{Uji Normalitas Residual}

Uji normalitas bertujuan untuk menguji apakah dalam sebuah model regresi, variabel penganggu atau residual mempunyai distribusi normal (Ghozali, 2013). Uji normalitas data dapat dilakukan melalui analisis grafik normal probability plot dengan dasar pengambilan keputusan jika data menyebar disekitar garis diagonal dan mengikuti arah garis diagonal, maka model regresi memenuhi asumsi normalitas. Jika data menyebar jauh dari diagonal dan tidak mengikuti arah garis diagonal, maka model regresi tidak memenuhi asumsi normalitas. Selain pendekatan grafik, uji normalitas data juga dapat dilakukan melalui analisis statistik yaitu analisis Kolmogorov Smirnov dengan dasar keputusan jika hasil nilai signifikansi $>0,05$ maka data residual terdistribusi normal. Sebaliknya jika signifikansi $<0,05$ maka data residual tidak terdistribusi dengan normal.

\section{Uji Multikolinieritas}

Uji multikolinieritas bertujuan untuk menguji apakah pada model regresi ditemukan adanya korelasi antar variabel bebas (independen) (Ghozali, 2013). Model regresi yang baik seharusnya tidak terjadi korelasi diantara variabel independen. Kriteria yang menunjukkan tidak adanya multikolinieritas dapat dideteksi dengan melihat nilai tolerance $>0,1$ dan variance inflation factor (VIF) $<10$.

\section{Uji Autokorelasi}

Uji autokorelasi bertujuan untuk menguji apakah dalam model regresi linear ada korelasi antara kesalahan pengganggu pada periode $t$ dengan kesalahan pengganggu pada periode t-1 sebelumnya (Ghozali, 2013). Model regresi yang baik adalah regresi yang bebas dari autokorelasi. Cara mendeteksi autolorelasi dengan menggunakan uji Durbin-Watson. Jika $\mathrm{du}<\mathrm{d}<4$-du maka dapat dikatakan data terbebas dari autokorelasi.

\section{Uji Heteroskedastisitas}

Uji heteroskedastisitas bertujuan untuk menguji apakah dalam model regresi terjadi ketidaksamaan variance dari residual satu pengamatan ke pengamatan yang lain (Ghozali, 2013). Apabila variance dari suatu residual satu pengamatan ke pengamatan yang lain tetap, maka dapat dikatakan homokedastisitas dan jika berbeda maka dikatakan heteroskedastisitas. Untuk menguji ada tidaknya heteroskedastisitas adalah dengan cara melihat grafik scatterplot antara nilai prediksi variabel dependen yaitu ZPRED dengan residualnya yaitu SRESID. Jika pada grafik scatterplot tidak ada pola yang jelas serta titik-titik menyebar diatas dan dibawah angka 0 pada sumbu Y maka tidak terjadi heteroskedastisitas. Sebaliknya, jika terdapat pola tertentu seperti titik-titik yang membentuk pola tertentu yang teratur (bergelombang, melebar kemudian menyempit), maka telah terjadi heteroskedastisitas.

\section{Analisis Regresi Linear Berganda}

Analisis regresi linear berganda dilakukan untuk mengukur kekuatan hubungan dan menunjukkan arah hubungan antara beberapa variabel independen dengan variabel dependen (Ghozali, 2013). Bentuk persamaan regresi berganda dalam penelitian ini dinyatakan sebagai berikut : 


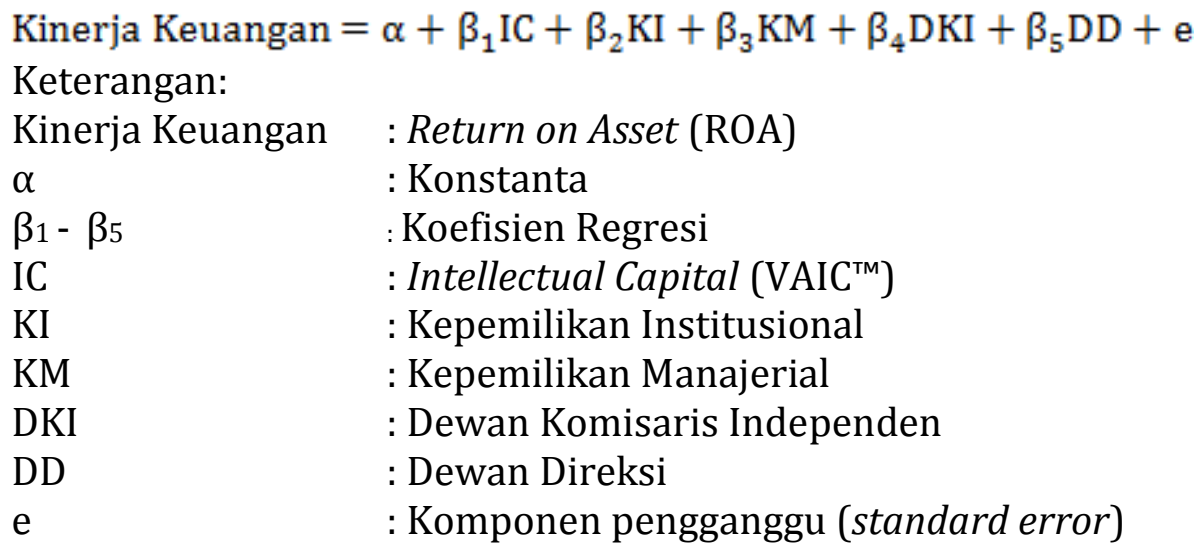

\section{Uji Hipotesis}

\section{Koefisien Determinasi $\left(\mathbf{R}^{2}\right)$}

Pengujian koefisien determinasi dilakukan untuk mengetahui seberapa jauh kemampuan model dalam menerangkan variasi variabel dependen (Ghozali, 2013). Nilai koefisien determinasi adalah antara nol dan satu. Nilai $\mathrm{R}^{2}$ yang kecil berarti kemampuan variabel-variabel independen dalam menjelaskan variasi variabel dependen amat terbatas. Nilai yang mendekati satu berarti variabel-variabel independen memberikan hampir semua informasi yang dibutuhkan untuk memprediksi variabel dependen.

\section{Uji Signifikansi Simultan (Uji F)}

Menurut Ghozali (2013) uji F dilakukan untuk mengetahui apakah seluruh variabel independen dalam model regresi mempunyai pengaruh secara bersama-sama terhadap variabel dependen. Jika signifikansi $\mathrm{F}>0,05$ maka secara bersama-sama variabel independen tidak memiliki pengaruh terhadap variabel dependen. Sedangkan jika nilai signifikansi $F<0,05$ maka secara bersama-sama variabel independen memiliki pengaruh terhadap variabel dependen.

\section{Uji t (Uji Parsial)}

Uji t dilakukan untuk mengetahui pengaruh variabel independen terhadap variabel dependen secara parsial dalam persamaan regresi berganda. Signifikan tidaknya pengaruh variabel independen terhadap variabel dependen dapat dilakukan dengan melihat nilai signifikansi. Jika nilai signifikansi lebih kecil dari 0,05 maka terdapat pengaruh antara variabel independen dengan variabel dependen.

\section{HASIL PENELITIAN DAN PEMBAHASAN Analisis Statistik Deskriptif}

Tabel 1

Hasil Statistik Deskriptif

Descriptive Statistics

\begin{tabular}{|l|r|r|r|r|r|}
\hline & $\mathrm{N}$ & \multicolumn{1}{|c|}{ Minimum } & \multicolumn{1}{c|}{ Maximum } & \multicolumn{1}{c|}{ Mean } & \multicolumn{1}{c|}{ Std. Deviation } \\
\hline Kinerja Keuangan & 188 &, 0004 &, 3720 &, 077523 &, 0722926 \\
Intellectual Capital & 188 &, 0541 & 7,6301 & 2,732574 & 1,3132350 \\
Kepemilikan Institusional & 188 &, 0000 & 99,7300 & 72,089764 & 24,8171893 \\
Kepemilikan Manajerial & 188 &, 0000 & 87,5033 & 5,804544 & 14,9339640 \\
Dewan Komisaris & 188 & 25,0000 & 80,0000 & 40,060427 & 9,4348572 \\
Independen & 188 & 2 & 16 & 5,64 & 2,734 \\
Dewan Direksi & & & &
\end{tabular}


\begin{tabular}{|l|r|l|l|l|} 
Lalid N (listwise) & 188 & & \\
\hline
\end{tabular}

Sumber: Output IBM SPSS Versi 20

Pada tabel diatas dapat dilihat bahwa nilai rata-rata dari kinerja keuangan (ROA) perusahaan manufaktur dari tahun 2015 sampai dengan tahun 2017 adalah 0,077523. Hal ini berarti setiap rupiah dari aset yang digunakan perusahaan dapat menghasilkan laba sebesar Rp. 0,0775. Nilai kinerja keuangan (ROA) tertinggi yaitu sebesar 0,3720 sedangkan nilai terendah yaitu 0,0004. Hal ini menunjukkan bahwa kemampuan manajemen dalam mengelola aset perusahaan belum cukup efisien sehingga belum menghasilkan keuntungan yang besar. Semakin tinggi nilai ROA, maka semakin efisien perusahaan menggunakan asetnya sehingga menunjukkan kinerja yang semakin baik karena akan menghasilkan keuntungan bagi perusahaan. Nilai standar deviasi variabel kinerja keuangan (ROA) menunjukkan angka 0,0722926 lebih kecil dibandingkan nilai rata-rata sebesar 0,077523 , hal ini mengindikasikan bahwa penyebaran data untuk kinerja keuangan (ROA) adalah merata, artinya tidak terdapat perbedaan data yang tinggi antara data satu dengan data yang lainnya.

Nilai rata-rata intellectual capital (VAICTM) adalah 2,732574 hal ini menunjukkan tingkat efisiensi penggunaan intellectual capital dan modal fisik dalam menghasilkan value added pada perusahaan manufaktur. Nilai intellectual capital tertinggi yaitu sebesar 7,6301 sedangkan nilai terendah yaitu 0,0541. Variabel intellectual capital memiliki nilai standar deviasi yaitu sebesar 1,3132350 nilai tersebut lebih kecil dari nilai rata-rata sebesar 2,732574 yang menandakan bahwa penyebaran data untuk intellectual capital adalah merata, artinya tidak terdapat perbedaan data yang tinggi antara data satu dengan data yang lainnya.

Kepemilikan institusional (KI) memiliki nilai rata-rata sebesar 72,089764 dengan nilai maksimum sebesar 99,7300 nilai minimum sebesar 0,0000. Kepemilikan institusional yang besar akan menyebabkan pengawasan yang lebih besar terhadap manajemen perusahaan sehingga meminimalisir penyelewengan yang mungkin dilakukan oleh manajer. Begitu sebaliknya, kepemilikan institusional yang kecil akan menyebabkan pengawasan terhadap manajemen perusahaan tidak terlalu efektif. Nilai standar deviasi kepemilikan institusional yaitu sebesar 24,8171893 yang menunjukkan angka lebih kecil dibandingkan nilai rata-rata sebesar 72,089764 yang berarti penyebaran data untuk kepemilikan institusional adalah merata, artinya tidak terdapat perbedaan data yang tinggi antara data satu dengan data yang lainnya.

Nilai rata-rata kepemilikan manajerial (KM) adalah 5,804544. Hal ini menunjukkan bahwa tidak terlalu banyak manajemen perusahaan (komisaris dan direksi) yang memiliki saham di dalam perusahaan. Nilai kepemilikan manajerial tertinggi menunjukkan angka sebesar 87,5033 dan nilai terendah sebesar 0,0000. Semakin besar kepemilikan saham oleh manajemen dalam perusahaan maka semakin produktif tindakan manajer dalam meningkatkan kinerja perusahaan. Kepemilikan manajerial memiliki nilai standar deviasi yaitu sebesar 14,9339640 nilai tersebut lebih besar dibandingkan nilai rata-rata sebesar 5,804544 yang mengindikasikan bahwa penyebaran data untuk kepemilikan manajerial adalah tidak merata, artinya terdapat perbedaan data yang tinggi antara data satu dengan data yang lainnya.

Nilai rata-rata dari dewan komisaris independen (DKI) perusahaan manufaktur dari tahun 2015 sampai dengan tahun 2017 adalah 40,060427. Nilai tersebut telah memenuhi Peraturan Otoritas Jasa Keuangan nomor 33/PJOK.04/2014 yang mewajibkan emiten memiliki komisaris independen minimal 30\% dari 
keseluruhan jumlah dewan komisaris. Nilai tertinggi dewan komisaris independen yaitu sebesar 80,0000 sedangkan nilai terendah sebesar 25,0000. Banyaknya anggota dewan komisaris independen akan membuat pengawasan lebih independen dalam suatu perusahaan. Nilai standar deviasi dewan komisaris independen yaitu 9,4348572 menunjukkan angka lebih kecil dari nilai rata-rata sebesar 40,060427 yang menandakan penyebaran data untuk dewan komisaris independen adalah merata, artinya tidak terdapat perbedaan data yang tinggi antara data satu dengan data yang lainnya.

Dewan direksi (DD) memiliki nilai rata-rata sebesar 5,64. Nilai tersebut telah memenuhi Peraturan Otoritas Jasa Keuangan nomor 33/POJK.04/2014 yang menyatakan paling kurang terdapat 2 orang anggota direksi dalam perusahaan. Nilai tertinggi dewan direksi sebesar 16 sedangkan nilai terendah sebesar 2 . Jumlah dewan direksi yang banyak akan meningkatkan kinerja perusahaan karena banyaknya sumber daya yang berperan dalam menentukan kebijakan dan strategi perusahaan. Dewan direksi memiliki standar deviasi sebesar 2,734 nilai tersebut lebih kecil dari nilai rata-rata sebesar 5,64 yang berarti penyebaran data untuk dewan direksi adalah merata, artinya tidak terdapat perbedaan data yang tinggi antara data satu dengan data yang lainnya.

\section{Uji Asumsi Klasik}

\section{Uji Normalitas Residual}

Hasil uji normalitas dilihat dari grafik normal probability plot adalah sebagai berikut:

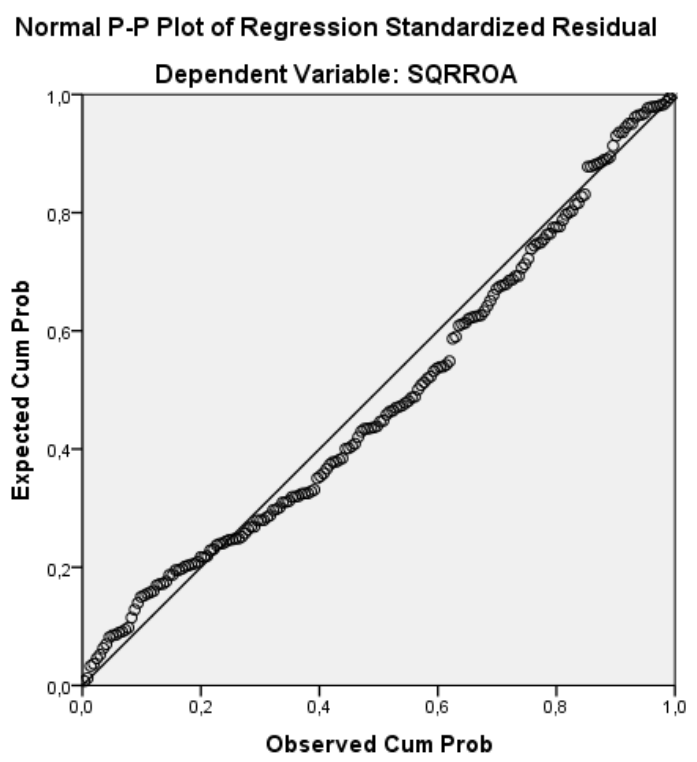

Gambar 1

Hasil Uji Normalitas

Sumber: Output IBM SPSS Versi 20.0

Berdasarkan hasil uji normalitas pada Gambar 1 diatas, dapat dilihat bahwa data menyebar disekitar garis diagonal dan mengikuti arah garis diagonal sehingga dapat disimpulkan bahwa data residual terdistribusi normal. Hasil uji normalitas dengan analisis Kolmogorov Smirnov dapat dilihat pada tabel dibawah ini: 
Hasil Uji Kolmogorov Smirnov

One-Sample Kolmogorov-Smirnov Test

\begin{tabular}{|ll|r|}
\hline & & \multicolumn{1}{|c|}{$\begin{array}{c}\text { Unstandardized } \\
\text { Residual }\end{array}$} \\
\hline $\mathrm{N}$ & Mean & 188 \\
Normal Parametersa,b & Std. Deviation & $0 \mathrm{E}-7$ \\
& Absolute &, 08349568 \\
& Positive &, 076 \\
Most Extreme Differences & Negative &, 076 \\
& &,- 051 \\
Kolmogorov-Smirnov Z & & 1,037 \\
Asymp. Sig. (2-tailed) &, 232 \\
\hline
\end{tabular}

a. Test distribution is Normal.

b. Calculated from data.

Sumber: Output IBM SPSS Versi 20.0

Hasil uji Kolmogorov Smirnov yang terdapat pada Tabel 2, menunjukkan bahwa nilai signifikansi 0,232 lebih besar dari tingkat signifikansi 0,05 sehingga dapat disimpulkan bahwa data residual terdistribusi normal.

\section{Uji Multikolinieritas}

Uji multikolinieritas bertujuan untuk menguji apakah pada model regresi ditemukan adanya korelasi antar variabel independen. Hasil uji multikolinieritas dapat dilihat pada tabel berikut ini:

Tabel 3

Hasil Uji Multikolinieritas

Coefficients $^{\mathrm{a}}$

\begin{tabular}{|c|c|c|c|c|c|c|c|}
\hline \multirow[t]{2}{*}{ Model } & \multicolumn{2}{|c|}{$\begin{array}{l}\text { Unstandardized } \\
\text { Coefficients }\end{array}$} & $\begin{array}{l}\text { Standardized } \\
\text { Coefficients }\end{array}$ & \multirow[t]{2}{*}{$t$} & \multirow[t]{2}{*}{ Sig. } & \multicolumn{2}{|c|}{ Collinearity Statistics } \\
\hline & B & Std. Error & Beta & & & Tolerance & VIF \\
\hline (Constant) &,- 326 & ,074 & & $-4,398$ &, 000 & & \\
\hline IC & ,227 & ,017 &, 690 & 13,566 &, 000 & 921 & 1,086 \\
\hline $1 \mathrm{KI}$ & 011 & ,005 & 171 & 2,373 & ,019 & 457 & 2,187 \\
\hline $\mathrm{KM}$ &, 006 & ,004 & ,099 & 1,367 & 173 & ,455 & 2,196 \\
\hline DKI & , 009 & , 009 & 051 & 1,021 & ,309 & 948 & 1,055 \\
\hline $\mathrm{DD}$ & ,024 & ,012 & 104 & 1,979 & ,049 &, 858 & 1,166 \\
\hline
\end{tabular}

a. Dependent Variable: ROA

Sumber: Output IBM SPSS Versi 20.0

Berdasarkan hasil uji multikolinieritas pada Tabel 3 diatas, dapat dilihat bahwa semua variabel independen masing-masing menunjukkan nilai tolerance lebih besar dari 0,1 dan nilai VIF tidak lebih dari 10. Dengan ini dapat disimpulkan tidak terjadi multikolinieritas antar variabel independen dalam model regresi.

\section{Uji Autokorelasi}

Uji autokorelasi bertujuan untuk menguji apakah dalam model regresi linear ada korelasi antara kesalahan pengganggu pada periode $t$ dengan kesalahan pengganggu pada periode t-1 sebelumnya. Hasil uji autokorelasi dapat dilihat pada tabel berikut ini: 
Hasil Uji Autokorelasi

Model Summary ${ }^{b}$

\begin{tabular}{|l|r|r|r|r|r|}
\hline Model & \multicolumn{1}{|c|}{$\mathrm{R}$} & R Square & Adjusted R Square & $\begin{array}{c}\text { Std. Error of the } \\
\text { Estimate }\end{array}$ & Durbin-Watson \\
\hline 1 &, $752^{\mathrm{a}}$ &, 566 &, 554 &, 08463 & 2,062 \\
\hline
\end{tabular}

a. Predictors: (Constant), DD, DKI, IC, KI, KM

b. Dependent Variable: ROA

Sumber: Output IBM SPSS Versi 20.0

Berdasarkan hasil uji autokorelasi pada Tabel 4, diperoleh hasil D-W statistik sebesar 2,062 dengan jumlah data $(\mathrm{n})=188$, variabel independen $(\mathrm{k})=2$, signifikansi $(\alpha)=5 \%$ maka didapatkan nilai $\mathrm{dL}=1,7398$ dan $\mathrm{dU}=1,7828$ sehingga $(4-\mathrm{dU})=4$ $1,7828=2,2172$. D-W statististik sebesar 2,062 terletak di daerah penerimaan H0 yaitu $1,7828<2,062<2,2172$. Hal ini menandakan bahwa model regresi penelitian ini terbebas dari autokorelasi.

\section{Uji Heteroskedastisitas}

Uji heteroskedastisitas bertujuan untuk menguji apakah dalam model regresi terjadi ketidaksamaan variance dari residual satu pengamatan ke pengamatan yang lain. Hasil uji heteroskedastisitas dilihat dari grafik scatterplot sebagai berikut:

Scatterplot

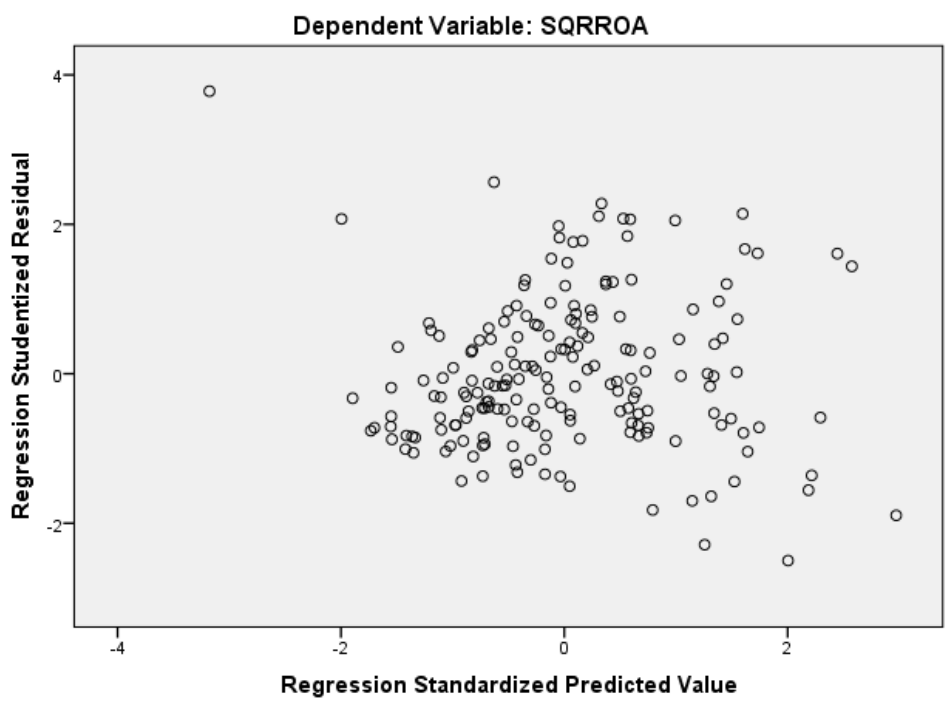

Gambar 2 Hasil Uji Heteroskedastisitas

Sumber: Output IBM SPSS Versi 20.0

Dari hasil uji heteroskedastisitas pada grafik Scatterplot diatas, dapat dilihat bahwa titik-titik menyebar secara acak tidak membentuk suatu pola yang jelas serta tersebar diatas dan dibawah angka 0 pada sumbu Y. Dengan demikian, dapat disimpulkan bahwa dalam model regresi tidak terjadi heteroskedastisitas.

\section{Analisis Regresi Berganda}

Berdasarkan hasil analisis data, maka dapat disusun persamaan regresi berganda dalam penelitian ini sebagai berikut: 
Kinerja Keuangan $=-0,326+0,227 \mathrm{IC}+0,011 \mathrm{KI}+0,006 \mathrm{KM}+0,009 \mathrm{DKI}+$ 0,024 DD

$$
+\mathrm{e}
$$

Dari persamaan regresi diatas, diperoleh nilai koefisien regresi variabel intellectual capital sebesar 0,227. Nilai koefisien regresi tersebut menunjukkan arah positif (searah) antara intellectual capital dengan kinerja keuangan. Hal ini mengidentifikasikan bahwa semakin tinggi intellectual capital maka semakin tinggi pula kinerja keuangan perusahaan. Koefisien regresi kepemilikan institusional bernilai 0,011. Nilai koefisien regresi tersebut menunjukkan arah positif (searah) antara kepemilikan institusional dengan kinerja keuangan. Hal ini menjelaskan bahwa semakin tinggi kepemilikan institusional maka semakin tinggi pula kinerja keuangan perusahaan.

Kepemilikan manajerial memiliki koefisien regresi sebesar 0,006. Nilai koefisien regresi tersebut menunjukkan arah positif (searah) antara kepemilikan manajerial dengan kinerja keuangan. Hal ini berarti semakin tinggi kepemilikan manajerial maka semakin tinggi pula kinerja keuangan perusahaan. Koefisien regresi dewan komisaris independen bernilai 0,009. Nilai koefisien regresi tersebut menunjukkan arah positif (searah) antara dewan komisaris independen dengan kinerja keuangan. Hal ini menjelaskan bahwa semakin banyak dewan komisaris independen maka semakin tinggi pula kinerja keuangan perusahaan. Dewan direksi memilki koefisien regresi sebesar 0,024. Nilai koefisien regresi tersebut menunjukkan arah positif (searah) antara dewan direksi dengan kinerja keuangan. Hal ini menjelaskan semakin banyak dewan direksi maka semakin tinggi pula kinerja keuangan perusahaan.

\section{Pengujian Hipotesis}

\section{Koefisien Determinasi ( $\left.\mathbf{R}^{2}\right)$}

Pengujian koefisien determinasi dilakukan untuk mengetahui seberapa besar variabel independen dalam model regresi dapat menjelaskan variabel dependen. Hasil uji determinasi dapat dilihat pada tabel dibawah ini:

Tabel 5

Hasil Uji Determinasi

Model Summaryb

\begin{tabular}{l|r|r|r|r|r|}
\hline Model & \multicolumn{1}{|c|}{$\mathrm{R}$} & R Square & Adjusted R Square & $\begin{array}{c}\text { Std. Error of the } \\
\text { Estimate }\end{array}$ & Durbin-Watson \\
\hline 1 &, $752^{\mathrm{a}}$ &, 566 &, 554 &, 08463 & 2,062 \\
\hline
\end{tabular}
a. Predictors: (Constant), DD, DKI, IC, KI, KM
b. Dependent Variable: ROA

Sumber: Output IBM SPSS Versi 20.0

Berdasarkan hasil uji determinasi pada Tabel 5 diatas, dapat dilihat bahwa koefisien determinasi $\left(\mathrm{R}^{2}\right)$ sebesar 0,554 hal ini menunjukkan 55,4\% variasi kinerja keuangan dapat dijelaskan oleh variasi kedua variabel independen yaitu intellectual capital dan mekanisme corporate governance. Sedangkan sisanya sebesar 44,6 \% $(100 \%-55,4 \%)$ dipengaruhi oleh variabel lain yang tidak terdapat dalam penelitian ini. 


\section{Uji Signifikansi Simultan (Uji F)}

Uji F dilakukan untuk mengetahui apakah seluruh variabel independen dalam model regresi mempunyai pengaruh secara bersama-sama terhadap variabel dependen. Hasil uji F dapat dilihat pada tabel dibawah ini:

Tabel 6

Hasil Uji F

ANOVAa

\begin{tabular}{|rl|r|r|r|r|r|}
\hline Model & Sum of Squares & df & Mean Square & F & Sig. \\
\hline \multirow{2}{*}{1} & Regression & 1,699 & 5 &, 340 & 47,427 &, $000^{\mathrm{b}}$ \\
& Residual & 1,304 & 182 &, 007 & & \\
& Total & 3,002 & 187 & & & \\
\hline
\end{tabular}

a. Dependent Variable: ROA

b. Predictors: (Constant), DD, DKI, IC, KI, KM

Sumber: Output IBM SPSS Versi 20.0

Berdasarkan hasil uji F pada Tabel 6 diatas, diperoleh nilai F sebesar 47,427 dengan nilai signifikansi sebesar 0,000 yakni lebih kecil dari 0,05. Hal ini menunjukkan bahwa variabel independen yaitu intellectual capital dan mekanisme corporate governance secara simultan mempengaruhi variabel dependen yaitu kinerja keuangan.

\section{Uji t (Uji Parsial)}

Uji t dilakukan untuk mengetahui pengaruh variabel independen terhadap variabel dependen secara parsial dalam persamaan regresi berganda. Hasil uji t dapat dilihat pada tabel dibawah ini:

Tabel 7

Hasil Uji t

Coefficients $^{\mathrm{a}}$

\begin{tabular}{|c|c|c|c|c|c|c|c|}
\hline \multirow[t]{2}{*}{ Model } & \multicolumn{2}{|c|}{$\begin{array}{l}\text { Unstandardized } \\
\text { Coefficients }\end{array}$} & $\begin{array}{l}\text { Standardized } \\
\text { Coefficients }\end{array}$ & \multirow[t]{2}{*}{$\mathrm{T}$} & \multirow[t]{2}{*}{ Sig. } & \multicolumn{2}{|c|}{ Collinearity Statistics } \\
\hline & $\mathrm{B}$ & Std. Error & Beta & & & Tolerance & VIF \\
\hline (Constant) &,- 326 &, 074 & & $-4,398$ &, 000 & & \\
\hline IC & ,227 & 017 & 690 & 13,566 &, 000 & ,921 & 1,086 \\
\hline $\mathrm{KI}$ &, 011 & ,005 & 171 & 2,373 &, 019 & , 457 & 2,187 \\
\hline $\mathrm{KM}$ & ,006 & ,004 & 099 & 1,367 & ,173 & ,455 & 2,196 \\
\hline DKI & ,009 & 009, & 051 & 1,021 & ,309 & 948, & 1,055 \\
\hline DD & ,024 &, 012 & 104 & 1,979 &, 049 & ,858 & 1,166 \\
\hline
\end{tabular}

a. Dependent Variable: ROA

Sumber: Output IBM SPSS Versi 20.0

Berdasarkan hasil uji t pada Tabel 7 diatas, intellectual capital (IC) memiliki nilai koefisien regresi sebesar 0,227 dan nilai signifikansi sebesar 0,000 lebih kecil dari tingkat signifikansi 0,05 yang menunjukkan bahwa intellectual capital berpengaruh positif terhadap kinerja keuangan. Kepemilikan institusional (KI) memiliki nilai koefisien regresi sebesar 0,011 dan nilai signifikansi sebesar 0,019 lebih kecil dari tingkat signifikansi 0,05 yang menunjukkan bahwa kepemilikan institusional berpengaruh positif terhadap kinerja keuangan. Kepemilikan manajerial (KM) memiliki nilai koefisien regresi sebesar 0,006 nilai signifikansi 0,173 lebih besar 
dari tingkat signifikansi 0,05 yang menunjukkan bahwa kepemilikan manajerial tidak memiliki pengaruh terhadap kinerja keuangan. Dewan komisaris independen (DKI) memiliki nilai koefisien regresi sebesar 0,009 dan nilai signifikansi sebesar 0,309 lebih besar dari tingkat signifikansi 0,05 yang menunjukkan bahwa dewan komisaris independen tidak berpengaruh terhadap kinerja keuangan. Dewan direksi (DD) memiliki nilai koefisien regresi sebesar 0,024 nilai signifikansi 0,049 lebih kecil dari tingkat signifikansi 0,05 yang menunjukkan bahwa dewan direksi berpengaruh terhadap kinerja keuangan.

\section{PEMBAHASAN HASIL UJI HIPOTESIS}

\section{Pengaruh Intellectual Capital terhadap Kinerja Keuangan Perusahaan}

Berdasarkan hasil uji t (uji parsial) pada Tabel 7, variabel intellectual capital memiliki nilai koefisien regresi $=0,227$, nilai Sig $=0,000$ berada dibawah 0,05 yang berarti memiliki pengaruh positif terhadap kinerja keuangan. Hasil analisis ini menunjukkan bahwa intellectual capital berpengaruh positif terhadap kinerja keuangan, sehingga hipotesis 1 yang menyatakan "intellectual capital berpengaruh positif terhadap kinerja keuangan perusahaan" diterima.

Pengelolaan intellectual capital yang baik dalam perusahaan dapat menciptakan value added yang berguna untuk meningkatkan kinerja keuangan perusahaan. Semakin baik pengelolaan intellectual capital maka akan menghasilkan kinerja keuangan yang baik bagi perusahaan. Selain itu, penggunaan sumber daya perusahaan secara efisien dan ekonomis akan meningkatkan laba perusahaan. Perusahaan yang memanfaatkan intellectual capital yang dimiliki dengan baik akan dapat meningkatkan profitabilitasnya. Hasil penelitian ini sejalan dengan penelitian Prastya (2013) yang membuktikan bahwa intellectual capital berpengaruh terhadap kinerja keuangan.

\section{Pengaruh Mekanisme Corporate Governance terhadap Kinerja Keuangan Perusahaan}

Dari hasil uji t (uji parsial) pada Tabel 7, indikator kepemilikan institusional memiliki nilai koefisien regresi $=0,011$, nilai Sig $=0,019$ berada diatas 0,05 yang berarti memiliki pengaruh positif terhadap kinerja keuangan. Rata-rata persentase kepemilikan institusional dalam penelitian ini lebih dari 70\%. Kepemilikan institusional yang tinggi dapat menyebabkan pengawasan yang semakin ketat dari pihak institusi terhadap kinerja manajemen dalam mengelola perusahaan. Hal ini menimbulkan tekanan pihak institusi yang semakin tinggi terhadap manajemen perusahaan untuk memaksimalkan keuntungan perusahaan yang diukur dengan return on assets (ROA). Hasil penelitian ini sesuai dengan penelitian Rimardhani dkk., (2016) yang menyatakan bahwa kepemilikan institusional berpengaruh positif dan signifikan terhadap kinerja keuangan.

Indikator kepemilikan manajerial memiliki nilai koefisien regresi $=0,006$, nilai Sig $=0,173$. Nilai signifikansi berada diatas 0,05 yang berarti tidak memiliki pengaruh terhadap kinerja keuangan. Rata-rata persentase kepemilikan manajerial dalam penelitian ini berkisar 5\%. Rendahnya persentase kepemilikan manajerial menyebabkan manajer kurang maksimal dalam menjalankan tugasnya untuk memaksimalkan kekayaan pemegang saham yaitu meningkatkan kinerja perusahaan. Dengan demikian, penyelarasan kepentingan antara pemegang saham dan manajer kurang dapat terwujud. Jika manajemen memiliki saham dalam perusahaan, maka 
manajemen akan meningkatkan kinerjanya sehingga kinerja keuangan perusahaan juga meningkat. Sebaliknya, jika pihak manajerial tidak memiliki saham dalam perusahaan, maka manajemen cenderung bertindak untuk kepentingannya dibandingkan kepentingan pemegang saham sehingga kinerja keuangan perusahaan tidak meningkat. Hasil penelitian ini mendukung penelitian Sari dan Priyadi (2017) mengemukakan bahwa kepemilikan manajerial berpengaruh negatif terhadap kinerja keuangan. Tertius dan Christiawan (2015) juga menyatakan bahwa kepemilikan manajerial tidak berpengaruh signifikan terhadap kinerja keuangan perusahaan.

Dari hasil uji t (uji parsial) pada Tabel 7, diperoleh nilai koefisien regresi $=$ 0,009 , nilai Sig $=0,309$ dari indikator dewan komisaris independen. Nilai signifikansi berada diatas 0,05 yang berarti tidak memiliki pengaruh terhadap kinerja keuangan. Rata-rata jumlah dewan komisaris independen dalam penelitian ini telah memenuhi Peraturan Otoritas Jasa Keuangan nomor 3/PJOK.04/2014 yang mewajibkan emiten memiliki komisaris independen minimal 30\% dari keseluruhan jumlah dewan komisaris. Namun keberadaan dewan komisaris independen dalam perusahaan hanya untuk memenuhi regulasi tanpa mengoptimalkan peran dewan komisaris independen sebagai pengawas kinerja manajemen dalam mengelola perusahan. Dengan demikian, dewan komisaris independen belum independensi dan belum menjalankan fungsi monitoring yang baik sehingga kinerja keuangan tidak meningkat. Hasil penelitian ini konsisten dengan penelitian Rimardhani dkk., (2016) serta Tertius dan Christiawan (2015) yang mengemukakan bahwa dewan komisaris independen berpengaruh negatif terhadap kinerja keuangan perusahaan. Sulistyowati dan Fidiana (2017) juga membuktikan bahwa dewan komisaris independen tidak berpengaruh terhadap kinerja keuangan perusahaan.

Dewan direksi memiliki nilai koefisien regresi $=0,024$, nilai Sig $=0,049$ berada dibawah 0,05 yang berarti memiliki pengaruh positif terhadap kinerja keuangan. Hasil ini menunjukkan bahwa jumlah dewan direksi dalam suatu perusahaan mempengaruhi tinggi rendahnya kinerja keuangan perusahaan. Semakin banyak dewan direksi dalam perusahaan maka fungsi pengelolaan dan koordinasi dalam perusahaan semakin baik. Dengan adanya dewan direksi maka akan dapat mengurangi konflik agensi dalam perusahaan sehingga perusahaan lebih fokus dalam meningkatkan nilai dan kinerja keuangan perusahaan. Hasil penelitian ini sesuai dengan penelitian Sulistyowati dan Fidiana (2017) serta Putra dan Fidiana (2017) yang membuktikan bahwa dewan direksi memberikan pengaruh positif terhadap kinerja keuangan perusahaan.

Dari empat indikator mekanisme corporate governance yang diteliti, hanya dua indikator yang berpengaruh positif terhadap kinerja keuangan yaitu kepemilikan institusional dan dewan direksi. Sedangkan dua indikator lainnya yaitu kepemilikan manajerial dan dewan komisaris independen tidak berpengaruh terhadap kinerja keuangan perusahaan. Dengan demikian, hipotesis 2 yang menyatakan "mekanisme corporate governance berpengaruh positif terhadap kinerja keuangan perusahaan" ditolak.

\section{Pengaruh Intellectual Capital dan Mekanisme Corporate Governance dengan Kinerja Keuangan Perusahaan}

Berdasarkan hasil uji F pada Tabel 6, diperoleh nilai Sig $=0,000$. Nilai signifikansi berada dibawah 0,05 hal ini menandakan bahwa variabel independen yaitu intellectual capital dan mekanisme corporate governance secara simultan 
mempengaruhi variabel dependen yaitu kinerja keuangan. Hasil analisis ini menunjukkan bahwa intellectual capital dan mekanisme corporate governance berpengaruh positif terhadap kinerja keuangan, sehingga hipotesis 3 yang menyatakan "intellectual capital dan mekanisme corporate governance berpengaruh positif terhadap kinerja keuangan perusahaan" diterima.

Hasil ini menunjukkan bahwa intellectual capital dan mekanisme corporate governance memiliki kontribusi terhadap peningkatan kinerja keuangan perusahaan menjadi lebih baik. Perusahaan yang mengelola dan memanfaatkan sumber daya yang dimilikinya dengan baik akan memperoleh keunggulan kompetitif dan menciptakan nilai tambah bagi perusahaan tersebut. Sedangkan mekanisme corporate governance dapat menselaraskan perbedaan kepentingan antara pihak agent dan principal sehingga pengelolaan perusahaan dapat berjalan dengan baik yang dapat meningkatkan kinerja keuangan perusahaan. Hasil penelitian ini sesuai dengan penelitian Sari dan Priyadi (2017) membuktikan bahwa intellectual capital dan corporate governance secara simultan berpengaruh terhadap kinerja perusahaan.

\section{KESIMPULAN DAN SARAN Kesimpulan}

Penelitian ini bertujuan untuk mengetahui pengaruh intellectual capital dan mekanisme corporate governance terhadap kinerja keuangan perusahaan manufaktur yang terdaftar di Bursa Efek Indonesia selama tahun 2015-2017. Kinerja keuangan perusahaan diukur dengan Return on Asset (ROA). Intellectual capital dalam penelitian ini diukur dengan menggunakan metode Pulic yaitu VAIC ${ }^{\text {TM }}$ (Value Added Intellectual Coefficient). Mekanisme corporate governance diukur dengan indikator Kepemilikan Institusional, Kepemilikan Manajerial, Proporsi Dewan Komisaris Independen, dan Dewan Direksi. Berdasarkan hasil analisis statistik deskriptif dan analisis regresi linear berganda, maka dapat disimpulkan sebagai berikut: (1) Intellectual capital berpengaruh positif terhadap kinerja keuangan (ROA). Mekanisme corporate governance tidak berpengaruh terhadap kinerja keuangan (ROA). (3) Intellectual capital dan mekanisme corporate governance secara simultan berpengaruh positif terhadap kinerja keuangan (ROA).

\section{Saran}

Berdasarkan penelitian yang telah dilakukan, terdapat beberapa saran yang dapat diberikan untuk penelitian selanjutnya yaitu: (1) Bagi peneliti selanjutnya dapat menambah variabel independen lain diluar variabel penelitian ini. Selain itu, penelitian berikutnya dapat menggunakan rasio keuangan yang lain untuk variabel dependen selain rasio profitabilitas. (2) Peneliti selanjutnya diharapkan untuk melakukan penelitian tentang pengaruh intellectual capital dan mekanisme corporate governance terhadap kinerja keuangan pada sektor lain yang terdaftar di Bursa Efek Indonesia (BEI). (3) Diharapkan bagi peneliti selanjutnya yang ingin melanjutkan penelitian ini dalam melakukan uji menggunakan model lain supaya memiliki hasil penelitian yang berbeda. (4) Peneliti selanjutnya dapat menambah periode penelitian sehingga memperoleh hasil penelitian yang lebih akurat dan dapat memprediksi hasil penelitian untuk jangka panjang. 


\section{DAFTAR PUSTAKA}

Agoes, Sukrisno., dan Ardana, I Cenik. 2014. Etika Bisnis dan Profesi: Tantangan Membangun Manusia Seutuhnya. Jakarta: Salemba Empat.

Barney, Jay. 1991. Firm Resources and Sustained Competitive Advantage. Journal of Management. Vol 17, No. 1, p. 99-120.

Baroroh, Niswah. 2013. Analisis Pengaruh Modal Intelektual Terhadap Kinerja Keuangan Perusahaan Manufaktur di Indonesia. Jurnal Dinamika Akuntansi, Vol 5, No. 2, p. 172-182.

Bontis, Nick., dan Nikitopoulos, Danny. 2001. Thought Leadership on Intellectual Capital. Journal of Intellectual Capital, Vol 2, No.3, p. 183-191.

Bontis, Nick., Keow, W.C.C., dan Richardson, S. 2000. Intellectual Capital and Business Performance in Malaysian Industries. Journal of Intellectual Capital. Vol 1, No.1, p. 85-100.

Bukh, N.P., C. Nielsen, P. Gormsen, dan J. Mouritsen. 2005. Disclosure of Information on Intellectual Capital in Danish IPO Prospectuses. Accounting, Auditing \& Accountability Journal, Vol 1, No. 6, p. 713-732.

Bursa Efek Indonesia. (2015-2017). Laporan Tahunan Perusahaan Manufaktur yang Terdaftar di Bursa Efek Indonesia dari tahun 2015 sampai dengan tahun 2017. Ditelusuri 4-11 April 2018. https://www.idx.co.id/.

Effendi, Muh. Arief. 2016. The Power of Good Corporate Governance: Teori dan Implementasi. Jakarta: Salemba Empat.

Fahmi, Irham. 2014. Etika Bisnis: Teori, Kasus dan Solusi. Bandung: Alfabeta cv.

Ghozali, Imam. 2013. Aplikasi Analisis Multivariate dengan Program IBM SPSS 21. Semarang: Badan Penerbit Universitas Diponegoro.

Hanafi, Mamduh M., dan Halim, Abdul. 2005. Analisis Laporan Keuangan. Edisi Kedua. Yogyakarta: Unit Penerbit dan Percetakan AMP-YKPN.

Ikatan Akuntan Indonesia (IAI). 2014. Standar Akuntansi Keuangan: Per Efektif 1 Januari 2015. Jakarta: IAI.

Peraturan Otoritas Jasa Keuangan Nomor 33/POJK.04/2014 Tentang Direksi dan Dewan Komisaris Emiten atau Perusahaan Publik. Ditelusuri 8 April 2018. https://www.ojk.go.id/.

Prasetyantoko. 2008. Corporate Governance: Pendekatan Institusional. Jakarta: PT Gramedia Pustaka Utama.

Prastya, Onny Maretha. 2013. Pengaruh Modal Intelektual dan Tata Kelola Perusahaan Terhadap Kinerja Keuangan. Jurnal Ilmu Manajemen, Vol 1, No. 3, p. 1-13.

Pulic, Ante. 2004. Intellectual Capital - does it create or destroy value?. Measuring Business Excellent, Vol.8, No.1, p. 62-68.

Putra, Robby Hartono., dan Fidiana. 2017. Pengaruh Tata Kelola Perusahaan Terhadap Kinerja Keuangan Perusahaan. Jurnal Ilmu dan Riset Akuntansi, Vol 6, No. 8, p. 1-17.

Ramadhan, Rhonal., dan Kurnia. 2017. Pengaruh Intellectual Capital Terhadap Kinerja Keuangan pada Perusahaan Infrastruktur, Utilitas, dan Transportasi. Jurnal Ilmu dan Riset Akuntansi, Vol 6, No. 8, p. 1-16.

Rimardhani, Helfina., Hidayat, R.Rustam., dan Dwiatmanto. 2016. Pengaruh Mekanisme Corporate Governance Terhadap Profitabilitas Perusahaan (Studi pada Perusahaan BUMN yang Terdaftar di BEI Tahun 2012-2014). Jurnal Administrasi Bisnis, Vol 31, No. 1, p. 167-175. 
Salim, Selvi Meliza., dan Karyawati, Golrida. 2013. Pengaruh Modal Intelektual Terhadap Kinerja Keuangan. Jurnal of Business and Entrepreneurship, Vol 1, No. 2, p. 75-91.

Sari, Arum Puspita., dan Priyadi, Maswa Patuh. 2017. Pengaruh Intellectual Capital dan Corporate Governance Terhadap Kinerja Perusahaan. Jurnal Ilmu dan Riset Akuntansi, Vol 6, No. 7, p. 1-20.

Solikhah, B., Rohman, A., dan Meiranto, W. 2010. Implikasi Intellectual Capital Terhadap Financial Performance, Growth dan Market Value; Studi Empiris dengan Pendekatan Simplistic Specification. Simposium Nasional Akuntansi XIII Purwokerto. Oktober.

Sujarweni, V. Wiratna. 2018. Metodologi Penelitian Bisnis dan Ekonomi Pendekatan Kuantitatif. Yogyakarta: PUSTAKABARUPRESS.

Sulistyowati., dan Fidiana. 2017. Pengaruh Good Corporate Governance Terhadap Kinerja Keuangan pada Perusahaan Perbankan. Jurnal Ilmu dan Riset Akuntansi, Vol 6, No. 1, p. 121-137.

Tertius, Melia Agustina., dan Christiawan, Yulius Yogi. 2015. Pengaruh Good Corporate Governance Terhadap Kinerja Perusahaan pada Sektor Keuangan. Business Accounting Review, Vol 3, No. 1, p. 223-232.

Triastuty, Siska., dan Riduwan, Akhmad. 2017. Pengaruh Modal Intelektual dan Mekanisme Corporate Governance Terhadap Kinerja Keuangan. Jurnal Ilmu dan Riset Akuntansi, Vol 6, No. 2, p. 703-722.

Wardani, Fransisca Pangestu., dan Zulkilfi. 2017. Pengaruh Good Corporate Governance Terhadap Kinerja Keuangan (Studi Empiris pada Perusahaan Manufaktur yang Terdaftar di Bursa Efek Indonesia Tahun 2011-2015). Jurnal Kajian Bisnis, Vol 25, No. 2, p. 176-193.

Wijayani, Dianing Ratna. 2017. Pengaruh Intellectual Capital Terhadap Kinerja Keuangan Perusahaan Publik di Indonesia. Jurnal Riset Akuntansi dan Bisnis Airlangga, Vol 2, No. 1, p. 97-116. 